\title{
Teaching Techniques
}

\section{Bringing Urban Legends into the Classroom}

\author{
Stephen C. Goodwin
}

\section{Topic}

Urban legends are anecdotes that appear mysteriously and spontaneously in varying forms, are often false (but not necessarily so), contain an element of humor or horror, and make good storytelling (http://www.urbanlegends.com). Furthermore, because they are often entertaining and interesting, they provide excellent opportunities to gain the attention of students. Urban legends can be used to help students learn how to research a topic, analyze the existing or potential veracity of stories commonly repeated in society, and understand how telling lies or half-truths can be harmful.

\section{Lesson Objective}

1. Research the existing or potential veracity of selected urban legends.

2. Stimulate student discussion concerning myths and truths about urban legends related to health education concepts.

3. Highlight potential problems associated with telling half-truths or lies.

\section{Assessment Criteria}

Assessment depends on the methodology and focus of the lesson. Some options:

1. Did the students select accurate sources of health information?

2 . If the teacher provides materials, did the students glean the appropriate information and reach a logical conclusion from the information presented?

Stephen C. Goodwin, PhD, Assistant Professor, Dept. of Health and Exercise Science, University of Delaware, Newark, DE 19716; goody@udel.edu. This manuscript was submitted July 2, 1997, and revised and accepted for publication November 24, 1997.

\section{Activities and Strategies}

To help students learn how to recognize the veracity of urban legends or other stories, present them with two or more urban legends related to the same content area. At least one of the urban legends should either be true or likely be true.

Depending on their age and ability, students should be organized into small groups. In some cases, they can work individually. The teacher may provide assistance in finding accurate sources of information on a particular group of legends.

Following their research, students present their findings to the class. If two or more groups research the same legend and reach contradictory conclusions, they present their reasons and allow other class members to ask questions. This is possible because many urban legends are based at least in part on fact, but either did not happen or are improbable. After discussion, tell the class the accepted belief regarding the legend's veracity.

Another option when using urban legends involves teaching students the potential problems associated with starting rumors. Mark Twain said, "One of the most striking differences between a cat and a lie is that a cat only has nine lives." Helping students understand the potential negative impact that urban legends can have represents an important concept in promoting responsible behavior.

\section{Examples of Urban Legends}

1) Urban Legend: A woman gives birth to twins, one is Mulatto and one is White.

Veracity: This legend is true.' Obviously, the twins were fraternal. Many cases of similar occurrences exist. ${ }^{2}$ This story provides an opportunity to help students understand the difference between identical and fraternal twins, and it can generate discussion concerning ethics, morals, and problems associated with having multiple sexual partners.

2) Urban Legend: A baby kidnaped in Mexico is killed and stuffed with drugs to smuggle across the border.

Veracity: This legend is not true. ${ }^{3}$ It can be used in a drug unit to explain why similar stories might be believed and as a help to understand the consequences associated with the drug trade.

3) Urban Legend: Subliminal messages influence people.

Veracity: Although this legend has been accepted for years, it is not true. ${ }^{4}$ The account of movie theaters increas- 
ing food sales by placing single frame pictures of food in the movies has been found untrue. ${ }^{5}$ This legend can be used to debunk that account, or it can be used as an important lesson in a consumer health unit.

4) Urban Legend: A married couple is unable to conceive, and the man is told to stop taking hot baths/jacuzzis.

Veracity: This legend is true, ${ }^{6}$ and it can be used in a contraceptive/sexuality unit from a historical perspective because some people/tribes had men put their scrotums in hot water as an early form of birth control. Emphasize that this method is not recommended as a means to prevent pregnancy.

5) Urban Legend: Swimming right after eating causes cramps.

Veracity: This legend is not true. Swimming is no more likely to cause cramps than running or other forms of exercise. This legend can be used to examine the digestive process and the role of exercise in diverting the blood flow to accommodate added demands on the muscular system.

6) Urban Legend: Exposure to the cold increases one's risk of developing a cold.

Veracity: Although widely accepted, this legend is untrue. Colds develop when people are exposed to a specific pathogen, most commonly a rhinovirus or coronavirus. Such pathogens tend to be common in winter because people are inside more often than other times of the year. Also, dry heat dries out mucous membranes, which provide an initial line of defense against invading organisms. ${ }^{7}$ This information can be helpful in a unit on disease and the immune system.

\section{Cirade Level and Subject Area}

Considering the nature of urban legends, most will work effectively in a middle school or high school setting. Urban legends can be found for just about any content area.

\section{Materials and Resources}

The teacher needs an imagination, stories, an open mind, and resource materials. Web sites for locating stories/legends can be found at the following:

http://www.urbanlegends.com (the definitive site);

http://www.urbanlegends.com/afu.faq/tcontents.html (part of the above site);

http://spitfire.ecsel.psu.edu/ redjen/ul.html (has links to other sites and some information);

http://www.tweak.com/firstperson/urban/ (has a few legends);

http://www.web.co.za/arthur/what.htm (a few legends and information); and

http://www.nardis.com/ twchan/tell.html (provides a good explanation of what an urban legend is and has examples)

\section{References}

1. Verma RS, Luke S, Dhawan P. Twins with different fathers. Lancet. 1992;399:(Jan. 4):63-64.

2. Terasaki PI, Gjertson D, Bernoco D, Perdue S, Mickey MR, Bond J. Twins with two different fathers identified by HLA. New Engl J Med. 1978;(11):590-592.

3. Buchanan E. The Corpse Had A Familiar Face: Covering Miami, America's Hottest Beat. New York, NY: Random House; 1987:157.

4. Vokey JR, Read JD.Subliminal messages: between the devil and the media. 1985;40:1231-1239.

5. Moore TE. Subliminal advertising: what you see is what you get. $J$ Marketing. 1982;46:38-47.

6. Caimie AB, Leach KE. Quantitative studies of cytological damage in mouse testis produced by exposure to heat. Can J Genet Cytol. 1980;22(1):93-102.

7. Clayman CB, ed. The American Medical Association Home Medical Encyclopedia: $A-H$. New York: Random House; 1989. 